\title{
PENAPISAN DAN POLA PERTUMBUHAN BAKTERI KITINOLITIK DARI CANGKANG RAJUNGAN (Portunus pelagicus)
}

\author{
Sudin ${ }^{1}$; Rieny Sulistijowati ${ }^{\star 1}$; Rita Marsuci Harmain \\ 1Jurusan Teknologi Hasil Perikanan, Fakultas Perikanan dan IImu Kelautan, Universitas Negeri Gorontalo, \\ Jl.Jenderal Sudirman No.06, Kota Gorontalo 96128, Gorontalo, Indonesia \\ *Korespondensi: rienysulistijowati@ung.ac.id \\ (Diterima 09-05-2020; Direvisi 10-09-2020; Dipublikasi 14-05-2020)
}

\begin{abstract}
ABSTRAK
Penapisan bakteri kitinolitik dari cangkang rajungan (Portunus pelagicus) telah dilakukan. Penelitian ini bertujuan untuk memperoleh isolat bakteri kitinolitik, mengetahui zona aktivitas kualitatif kitinase serta pola pertumbuhan yang dihasilkan oleh bakteri kitinolitik dari cangkang rajungan (Portunus pelagicus). Metode penelitian yang digunakan adalah metode penelitian deskriptif. Penelitian ini terdiri atas 3 tahap, yaitu skrining bakteri kitinolitik (isolasi dan identifikasi makroskopis dan mikroskopis), penentuan zona aktivitas kualitatif kitinase serta pola kurva pertumbuhannya. Isolat bakteri kitinolitik yang berhasil ditumbuhkan, diperoleh indeks kitinolitik tertinggi sebesar 1. Hasil identifikasi makroskopis dan mikroskopis menunjukkan isolat bakteri kitinolitik merupakan bakteri gram negatif berbentuk batang. Awal fase logaritmik terjadi pada waktu inkubasi 2 jam hingga 10 jam.
\end{abstract}

Kata kunci : Bakteri Kitinolik; Kitinase; Logaritmik; Portunus pelagicus

\section{ABSTRACT}

Screening of chitinolytic bacteria from crab shells (Portunus pelagicus) was carried out. This study aims to obtain chitinolytic bacterial isolates, determine the zone of chitinase activity qualitative produced and growth pattern by chitinolytic bacteria from crab shells (Portunus pelagicus). The research method used is descriptive research method. This study consisted of 3 stages, namely screening for chitinolytic bacteria (isolation and macroscopic and microscopic identification), determination of the zone of chitinase activity qualitative and growth curve produced by chitinolytic bacteria. Chitinolytic bacterial isolates that were successfully grown, obtained the highest chitinolytic index of 1. Macroscopic and microscopic identification results showed that chitinolytic bacterial isolates were gram-negative rod-shaped bacteria. Logaritmic gowth at $2^{\text {nd }}$ to ten ${ }^{\text {th }}$ hours incubation.

Keywords : Chitinolic bacteria;Chitinase;Logaritmic; Portunus pelagicus. 


\section{PENDAHULUAN}

Penerapan bioteknologi terhadap kitin yang terus berkembang adalah pemanfaatan enzim dari mikroorganisme untuk biodegradasi. Dalam biodegradasi, enzim dari mikroorganisme berperan untuk memecah molekul besar atau polimer kitin menjadi produk yang dapat dimanfaatkan. Secara umum enzim yang mendegradasi kitin adalah jenis enzim kitinase (Purkan dkk. 2016).

Bakteri penghasil enzim kitinase atau bakteri kitinolitik dapat ditemukan pada habitathabitat yang mengandung kitin yang tinggi, salah satunya adalah cangkang rajungan. Cangkang rajungan (Portunus pelagicus) dapat diperoleh dari limbah hasil pengolahan maupun segar. Cangkang rajungan segar diduga dapat ditemukan bakteri kitinolitik karena belum mengalami proses pengolahan, sedangkan limbah hasil pengolahan (perebusan), dimungkinkan bakteri yang dimaksud sudah mengalami kematian (Chasanah $d k k$. 2009).

Aplikasi enzim kitinase dapat digunakan sebagai pengolahan kitin secara enzimatis. Upaya pengolahan kitin dapat dilakukan secara enzimatis maupun kimiawi (Cahyani, 2013). Metode enzimatis menggunakan enzim maupun bakteri untuk deproteinasi dengan penambahan enzim atau dengan melibatkan kitinase untuk mendegradasi kitin. Sedangkan kimiawi yaitu dengan cara demineralisasi dan deproteinasi melalui penambahan asam atau basa kuat dalam hal ini $\mathrm{HCl}$ dan $\mathrm{NaOH}$ (Younes, $d k k, 2012$ ).

Metode sintesa kitin secara kimiawi merupakan metode yang mudah dan murah akan tetapi kurang ramah lingkungan, karena sangat banyak menggunakan bahan kimia $(\mathrm{HCl}$ dan $\mathrm{NaOH}$ ) (Soeka dan Triana, 2016). Teknik produksi secara enzimatis dianggap lebih baik dibandingkan dengan teknik secara kimiawi karena proses ini sangat mudah, sederhana, cepat dan tidak menggunakan pelarut kimia sehingga mengurangi dampak negatif bagi lingkungan, serta meminimalkan bahaya yang berhubungan dengan penggunaan bahan kimia. Kelemahan dalam penggunaannya di bidang industri yaitu harganya yang mahal, membutuhkan kondisi optimum agar enzim bekerja maksimal, mudah terpengaruh kondisi lingkungan (Chasanah, $d k k, 2014)$.

Kebutuhan terhadap derivat kitin yang semakin meningkat mengakibatkan meningkatnya kebutuhan kitinase (Widyastuti, 2007 dalam Cahyani, 2013), sehingga perlu dilakukan penelitian untuk mengetahui adanya aktivitas enzim kitinase melalui isolasi bakteri dari cangkang rajungan. Beberapa penelitian telah mencoba menghidrolisis kitin dengan enzim yang dihasilkan oleh Aspergillus sp, Bacillus sp, Clostridium sp, Serratia sp, Aeromonas sp, dan Trichoderma sp. (Maggadani, 2012 dalam Purkan, dkk, 2014).

Isolat-isolat bakteri kitinolitik memiliki kemampuan mendegradasi kitin yang berbeda. 
Hal tersebut dapat disebabkan oleh jenis bakteri, pola pertumbuhan dan aktivitas enzim. Untuk memperoleh kemampuan degradasi yang baik perlu diketahui aktivitas enzimnya.

Berdasarkan latar belakang diatas, maka penulis berkeinginan untuk melakukan penelitian mengenai isolasi bakteri dan penentuan zona aktivitas kitinase bakteri kitinolitik.

\section{METODE PENELITIAN}

\section{Waktu dan Tempat}

Penelitian isolasi bakteri kitinolitik penghasil enzim kitinase dari cangkang rajungan (Portunus pelagicus) dilakukan di Stasiun Karantina Ikan, Pengendalian Mutu dan Keamanan Hasil Perikanan Kelas I Gorontalo.

\section{Alat dan Bahan}

Alat yang digunakan dalam penelitian ini meliputi tabung reaksi, jarum Ose, vorteks (V-1plus), gelas ukur, Beaker glass, Erlenmeyer, pH meter, pipet mikro, tip mikro, pengaduk, magneticstirrer (Jisico), cawan petri, oven, sendok bengkok, lampu bunsen, inkubator (IB11E), Laminar Air Flow (LAF), timbangan analitik, dan mikroskop (Olympus Binokuler CX22).

Bahan yang digunakan dalam penelitian ini antara lain, cangkang rajungan, kitin, koloidal kitin (kitin, $\mathrm{HCl}$ pekat Merck 100317 KgaA 64271 Darmstadt, NaOH Merck 106498 KgaA 64271 Darmstadt, akuades), media agar kitin (koloidal kitin, $\mathrm{KH}_{2} \mathrm{PO}_{4}$ Merck 104877 KgaA
64293 Darmstadt, $\mathrm{MgSO}_{4} .7 \mathrm{H}_{2} \mathrm{O}$ Merck 105886 KgaA 64271 Darmstadt, Ekstrak yeast Merck LP0021 Oxoid, agar Merck GRMO26 Himedia, aquades), NA (Nutrient agar) Merck KgaA 64271 Darmstadt, allumunium foil.

\section{Prosedur penelitian}

Penelitian ini dilakukan dengan menggunakan metode penelitian deskriptif. Sampel dianalisis di laboratorium, data yang diperoleh adalah data kualitatif.

\section{Pengambilan dan Preparasi Sampel Cangkang Rajungan (Portunus pelagicus) \\ Sampel cangkang rajungan segar diambil} dari nelayan penangkap rajungan di Desa Katialada Kecamatan Kwandang Kabupaten Gorontalo Utara. Sampel tersebut dimasukkan ke dalam coolbox berisi es batu yang dilapisi plastik kemudian ditutup. Tujuan es batu dilapisi dengan plastik adalah agar rajungan dan es batu tidak bersentuhan secara langsung.

\section{Pembuatan Koloidal Kitin}

Pembuatan koloidal kitin menggunakan metode hidrolisis parsial. Menurut Arnold \& Solomon (1986), Koloidal kitin dibuat dengan melarutkan $10 \mathrm{~g}$ kitin dalam $200 \mathrm{ml} \mathrm{HCl}$ pekat dalam gelas beker, kemudian didiamkan semalaman dalam keadaan tertutup pada suhu $4^{\circ} \mathrm{C}$. Larutan kemudian disaring menggunakan glass wool, lalu filtrat dicampur dengan $100 \mathrm{ml}$ akuades dingin dan ditambahkan $\mathrm{NaOH} 12 \mathrm{~N}$ hingga $\mathrm{pH}$ mencapai $\mathrm{pH} 7$ (netral). Larutan kemudian disentrifugasi dengan kecepatan 8000 rpm selama 20 menit. Supernatan dibuang, endapan ditambah akuades, 
kemudian disentrifugasi kembali dengan kecepatan $8000 \mathrm{rpm}$ selama 20 menit. Endapan yang terbentuk merupakan koloidal kitin yang siap digunakan.

\section{Isolasi Bakteri Kitinolitik dari Cangkang Rajungan (Portunus pelagicus)}

Isolasi bakteri kitinolitik dari cangkang rajungan dilakukan dengan mengambil cottonbud yang sudah disterilkan. Setelah itu, menggoreskan cottonbud pada cangkang dengan cara ditekan dan diputar. Kemudian memasukkan cottonbud ke dalam tabung reaksi pengenceran $10^{-1}$ yang berisi $9 \mathrm{~mL}$ aquades steril. Untuk mendapatkan pengenceran $10^{-2}$ mengambil $1 \mathrm{~mL}$ dari pengenceran 10-1 dengan menggunakan mikropipet dilakukan dengan cara dimasukkan ke dalam tabung reaksi yang berisi $9 \mathrm{~mL}$ aquades steril, demikian seterusnya sampai dibuat pengenceran $10^{-6}$. Pengenceran tiga terakhir diambil, lalu diinokulasi pada media yang mengandung koloidal kitin (Fitriani et al, 2018).

Proses isolasi bakteri dilakukan dengan menggunakan media isolasi yang selektif yaitu media agar kitin. Proses pembuatan media agar kitin yaitu 2,5 gram koloidal kitin dilarutkan terlebih dahulu dalam $5 \mathrm{ml}$ akuades. Setelah itu ditambahkan $0,5 \mathrm{gr}$ MgSO4.7H2O, 0,1 gr $\mathrm{KH}_{2} \mathrm{PO}_{4}, 0,5 \mathrm{gr}$ ekstrak yeast, $7,5 \mathrm{gr}$ agar dan $495 \mathrm{ml}$ akuades. Semua bahan yang telah dicampur kemudian dididihkan. Media disterilkan pada suhu $121^{\circ} \mathrm{C}$ selama $15-20$ menit. Setelah disterilkan, media dituang http://ejurnal.ung.ac.id/index.php/jfpj/issue/arch sebanyak $5 \mathrm{ml}$ dalam tiap cawan petri. Masingmasing tingkat pengenceran tiga terakhir $\left(10^{-4}\right.$, $10^{-5}, 10^{-6}$ ) diinokulasi ke media agar kitin masing-masing sebanyak $1 \mathrm{ml}$ dengan menggunakan mikropipet, selanjutnya masing-masing cawan petri dibungkus dan diinkubasi pada suhu $30^{\circ} \mathrm{C}$ selama $2 \times 24$ jam.

\section{Pemurnian dan Identifikasi Kultur Bakteri Kitinolitik}

Pemurnian kultur bakteri kitinolitik menggunakan metode gores kuadran. Hasil dari isolasi bakteri yang didapatkan kemudian dilakukan proses pemurnian kultur bakteri untuk mendapatkan koloni isolat murni. Langkah pertama yang dilakukan dalam proses pemurnian bakteri adalah memilih koloni-koloni yang berbeda dari hasil isolasi bakteri. Koloni bakteri kemudian diinokulasikan pada permukaan medium agar kitin menggunakan jarum ose steril dengan metode gores kuadran untuk mendapatkan koloni yang terpisah. Setelah itu, diinkubasi pada suhu $30^{\circ} \mathrm{C}$ selama 48 jam (Kamil et al, 2007). Selanjutnya dilakukan pengamatan secara makroskopis dan mikroskopis.

Identifikasi secara makroskopis dilakukan secara langsung, sedangkan identifikasi mikroskopis dilakukan dengan cara melakukan pewarnaan Gram. Pengecatan Gram dilakukan dengan mengambil sebanyak 1 ose isolat bakteri diencerkan dalam $3 \mathrm{~mL}$ akuades steril dan di ambil $10 \mu$ l lalu diletakkan pada gelas obyek dan difiksasi. Selanjutnya ditambahkan sebanyak 1 tetes kristal violet (Gram A) selama 
1 menit kemudian dicuci dengan air mengalir dan di keringanginkan. Setelah kering ditambahkan 1 tetes larutan iodine (Gram B). Setelah 1 menit kemudian dicuci dengan air mengalir. Selanjutnya isolat bakteri ditambah larutan aseton alkohol 95\% (Gram C) selama 30 detik dan dicuci dengan air mengalir. Kemudian isolat bakteri ditambahkan safranin (Gram D) selama 2 menit dan dicuci dengan air mengalir dan dikering anginkan, selanjutnya diamati dengan mikroskop. Bakteri Gram Positif berwarna ungu dan bakteri Gram negatif berwarna merah (Suryani, 2016).

\section{Penentuan Zona Aktivitas Kitinase Bakteri Kitinolitik Kualitatif}

Penentuan Zona aktivitas kitinase bakteri kitinolitik dilakukan dengan cara ditotolkan pada media agar kitin. Pada pengujian ini dilihat zona bening yang dihasilkan. Pengujian ini dilakukan melalui beberapa tahapan, yaitu:

Tahap pertama sebanyak satu ose bakteri yang ada pada isolat murni diambil dan dimasukkan ke dalam cawan petri yang berisi media agar kitin yang sudah memadat dengan cara ditotolkan. Tahap kedua bakteri diinkubasi pada suhu $30^{\circ} \mathrm{C}$ selama 72 jam. Tahap ketiga mengamati zona bening yang terbentuk dan mengukur luasan zona bening yang dihasilkan menggunakan penggaris (Chasanah, 2009).

Zona bening yang terdapat pada medium merupakan respon dari bakteri terhadap koloidal kitin yang ditambahkan dalam medium. Dari seluruh isolat murni yang diuji aktivitas kitinolitik, diambil 1 isolat yang menghasilkan indeks kitinolitik terbesar.

\section{Pola Pertumbuhan Bakteri Kitinolitik}

Pola pertumbuhan bakteri ditentukan dengan membuat kurva pertumbuhan bakteri kitinolitik. Isolat terpilih dimasukkan ke dalam $20 \mathrm{~mL}$ Luria Broth (sebagai larutan inokulum). Pembuatan media Luria Broth dilakukan dengan cara menyiapkan media Tripton $10 \mathrm{gr}$, yeast extract $10 \mathrm{gr}, \mathrm{NaCl} 0,1 \mathrm{gr}$ dan akuades $1000 \mathrm{ml}$. Selanjutnya diinkubasi pada suhu $30^{\circ} \mathrm{C}$ selama 24 jam dan dilakukan shaker dengan kecepatan 150 rpm. Sebanyak $2 \mathrm{~mL}$ larutan inokulum tersebut ditambahkan ke dalam $20 \mathrm{~mL}$ media yang sama dalam labu Erlenmeyer $100 \mathrm{~mL}$ dan diinkubasi pada kondisi yang sama, kemudian diambil sebanyak $1 \mathrm{~mL}$ setiap 2 jam sekali untuk diukur densitas optik (OD) bakteri sampai fase awal kematian. Pengukuran OD bakteri dilakukan dengan menggunakan spektrofotometer dan dibaca serapannya pada panjang gelombang $600 \mathrm{Nm}$. Kurva pertumbuhan ditentukan dengan membuat plot antara waktu inkubasi dan densitas optiknya (Purkan, 2014).

\section{HASIL DAN PEMBAHASAN}

\section{Isolasi dan Pemurnian Bakteri Kitinolitik}

Hasil isolasi bakteri setelah diinkubasi selama 48 jam pada suhu $30{ }^{\circ} \mathrm{C}$ menghasilkan bakteri yang tumbuh pada media agar kitin. Bakteri ditemukan hanya tumbuh pada cawan petri $10^{-4}$. 
Bakteri tersebut kemudian dipisahkan berdasarkan kenampakan koloni, bentuk dan warna yang berbeda. Hasil yang didapatkan terdapat 3 koloni yang berbeda, yaitu putih, krem dan kuning.

Hasil yang diperoleh dari proses pemurnian setelah diinkubasi selama 48 jam pada suhu $30^{\circ} \mathrm{C}$ menunjukkan adanya zona bening yang terbentuk pada koloni bakteri. Akan tetapi, zona bening hanya ditemukan pada bakteri berwarna krem dan putih. Selanjutnya kedua isolat tersebut dilakukan identifikasi secara makroskopis dan mikroskopis.

\section{Identifikasi Makroskopis dan Mikroskopis}

Berdasarkan hasil identifikasi makroskopis menunjukkan bahwa bakteri kitinolitik berbentuk bulat, berwarna putih dan krem, tepi koloni utuh (Gambar 1), sedangkan hasil identifikasi secara mikroskopis dengan pewarnaan gram menunjukkan bahwa bakteri kitinolitik merupakan bakteri gram negatif berbentuk basil (batang).

Morfologi koloni dan sel bakteri kitinolitik dapat dilihat pada Tabel 1.

Tabel 1. Morfologi koloni dan sel bakteri kitinolitik

\begin{tabular}{|c|c|c|c|c|c|}
\hline $\begin{array}{l}\text { Jenis } \\
\text { bakteri }\end{array}$ & $\begin{array}{l}\text { Warna } \\
\text { Koloni }\end{array}$ & $\begin{array}{l}\text { Bentuk } \\
\text { Koloni }\end{array}$ & $\begin{array}{l}\text { Elevasi } \\
\text { Koloni }\end{array}$ & Gram & $\begin{array}{l}\text { Bentuk } \\
\text { sel }\end{array}$ \\
\hline R1 & Putih & Bulat & Cembung & Negatif & Batang \\
\hline $\mathrm{R} 2$ & Krem & Bulat & Cembung & Negatif & Batang \\
\hline
\end{tabular}

Berdasarkan Tabel 1 isolat R1 menunjukkan warna koloni putih dan Isolat R2 menunjukkan warna koloni krem. Sedangkan dari segi bentuk dan elevasi koloni tidak ada perbedaaan antara isolat R1 dan R2. Keduanya memiliki bentuk koloni bulat dan elevasi koloni cembung.

Hasil pewarnaan gram kedua isolat bakteri kitinolitik R1 dan R2 menunjukkan gram negatif. Hal ini ditandai dengan kedua isolat setelah dilakukan pewarnaan gram berwarna merah. Menurut Lay (1994) dalam Dewi (2008) menyatakan bahwa Bakteri negatif pada pewarnaan gram berwarna merah disebabkan kompleks zat warna kristal violet larut pada saat pemberian larutan aseton, dan mengambil warna merah safranin. Umumnya bakteri gram negatif memiliki dinding sel dengan kandungan lipida yang tinggi, sehingga lipida larut oleh larutan aseton

\section{Aktivitas Kualitatif Kitinase Bakteri Kitinolitik}

Aktivitas enzim dari bakteri kitinolitik ditunjukkan dengan adanya zona bening yang terbentuk disekitar koloni. Zona bening tersebut membuktikan bahwa isolat mampu mendegradasi substrat kitin yang terkandung pada media agar kitin. Menurut Harman et al. (1993) menyatakan bahwa bakteri kitinolitik merupakan bakteri yang kompeten memproduksi enzim kitinase dan memanfaatkan kitinase untuk asimilasi kitin sebagai sumber karbon dan nitrogen.

Isolat bakteri yang dihasilkan dari cangkang rajungan menunjukkan adanya zona bening. Zona bening terbentuk akibat enzim 
kitinase yang dibebaskan keluar sel bakteri untuk memecah makromolekul kitin menjadi molekul kitin yang lebih kecil, sehingga bakteri dapat mengambil nutrisi dalam bentuk molekulmolekul kecil.

Hasil isolasi dan seleksi bakteri pada media kitin diketahui adanya bakteri yang tumbuh dengan tingkat pertumbuhan bakteri yang ditunjukkan dengan indeks kitinolitik yang berbeda-beda jumlahnya. Hal ini disebabkan karena perbedaan tingkat adaptasi bakteri dengan medium atau lingkungan hidupnya. Pada media padat selektif diketahui bahwa bakteri berpotensi sebagai penghasil kitinase dengan terbentuknya zona bening di sekitar koloni. Semakin banyak enzim yang dihasilkan maka zona bening juga akan semakin luas karena kitin yang terdegradasi semakin banyak (Suryani, 2016).

Hasil penelitian menunjukkan isolat IK 11 dari isolat R1 mempunyai indeks kitinolitik terbesar yaitu 1. Berbeda dengan hasil penelitian yang dilakukan Suryani (2016) mengemukakan bahwa isolat bakteri kitinolitik yang diperoleh memiliki indeks kitinolitik terbesar yaitu 7,59. Hasil penelitian Chasanah dkk. (2009) mengemukakan bahwa isolat bakteri kitinolitik yang diperoleh memiliki indeks kitinolitik terbesar 2,58. Perbedaan indeks kitinolitik tersebut selain disebabkan perbedaan tingkat adaptasi bakteri dengan medium atau lingkungan hidupnya, juga dapat disebabkan perbedaan jenis bakteri.Indeks kitinolitik menunjukkan kemampuan degradasi mikroba terhadap kitin. Semakin banyak enzim yang dihasilkan maka zona bening juga akan semakin luas karena kitin yang terdegradasi semakin banyak.

\section{Pola Pertumbuhan Bakteri Kitinolitik}

Pola pertumbuhan bakteri kitinolitik diperlukan untuk mengetahui fase-fase pertumbuhan pada isolat kitinolitik, sehingga dapat ditentukan fase logaritmik dimana suatu bakteri dapat digunakan sebagai inokulum. Berdasarkan pola pertumbuhan selama rentang waktu 24 jam (Gambar 1).

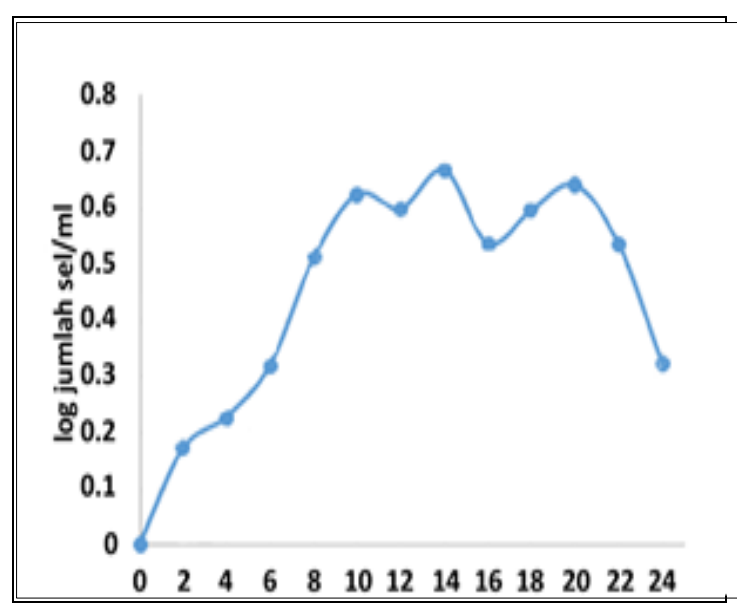

Waktu Inkubasi (jam)

Gambar 1. Kurva Pertumbuhan Bakteri Kitinolitik

Pola pertumbuhan bakteri kitinolitik diperlukan untuk mengetahui fase-fase pertumbuhan pada isolat kitinolitik, sehingga dapat ditentukan fase logaritmik dimana suatu bakteri dapat digunakan sebagai inokulum. Berdasarkan pola pertumbuhan selama rentang waktu 24 jam, bakteri isolat kitinolitik tidak tampak mengalami fase lag (adaptasi). Hal ini dapat terjadi karena fase adaptasi 
bakteri isolat kitinolitik sangat pendek sehingga tidak terlihat.

Menurut Setyati, dkk (2015) menyatakan bahwa singkatnya fase adaptasi bakteri disebabkan bakteri tersebut tumbuh pada media yang sama dengan media penyegaran di tahap sebelumnya maka penyesuaian diri dengan lingkungan yang baru berlangsung cepat. Respati menambahkan fase lag dapat berlangsung lambat bahkan cepat, biasanya dalam hitungan menit hingga jam tergantung jenis bakteri, umur biakan, dan nutrisi yang terdapat pada media.

Isolat bakteri kitinolitik ditumbuhkan dalam medium media Luria Broth yang mengandung yeast ekstrak, tripton, $\mathrm{NaCl}$ dan aquades. Yeast ekstrak merupakan bahan yang mengandung asam amino yang lengkap dan vitamin. Tripton berfungsi sebagai sumber karbon sekaligus sumber nitrogen bagi pertumbuhan bakteri, sedangkan $\mathrm{NaCl}$ digunakan untuk menjaga tekanan osmotik sel bakteri agar tidak pecah.

Awal fase logaritmik terjadi pada waktu inkubasi 2 jam hingga 10 jam, pada fase ini isolat bakteri kitinolitik mengalami fase pertumbuhan cepat dimana massa dan volume sel meningkat karena nutrisi pada media tercukupi sehingga dapat tumbuh dengan optimal. Cahyani (2013) menyatakan bahwa pada fase logaritmik aktivitas metabolisme berada pada kondisi optimum dan metabolisme paling aktif. Sintesis bahan sel sangat cepat dengan jumlah konstan terjadi pada fase ini, sehingga pada fase ini bakteri sangat baik apabila digunakan sebagai inokulum. Selanjutnya terjadi penurunan pada waktu inkubasi 12 jam dengan log sel 0,600, meskipun tidak menunjukkan penurunan yang drastis. Hal ini dapat disebabkan mulai berkurangnya nutrien. Setelah itu meningkat kembali pada waktu inkubasi 14 jam dengan log sel 0,669 yang merupakan awal dimulainya fase stasioner.

Fase stasioner terjadi pada waktu inkubasi 14 jam hingga 20 jam, meskipun pada waktu inkubasi 16 jam terjadi penurunan dengan log sel 0,538. Hal ini terjadi karena adanya senyawa metabolit sekunder hasil aktivitas metabolisme yang memicu terjadinya penurunan. Metabolit sekunder merupakan senyawa yang dihasilkan pada fase pertumbuhan stasioner. Senyawa yang dihasilkan antara lain antibiotik, toksin, vitamin, pigmen dan alkaloid. Sulistijowati (2012) mengemukakan bahwa pada fase stasioner menunjukkan terjadinya penumpukan metabolit hasil aktivitas metabolisme sel dan kandungan nutrien mulai habis. Akibatnya terjadi kompetisi nutrisi sehingga beberapa sel mati dan lainnya tetap tumbuh.

Waktu inkubasi 18 jam hingga 20 jam kembali terjadi peningkatan sel dengan log sel 0,597 dan 0,642 . Hal demikian bisa terjadi karena kompetisi sudah berkurang sehingga naik lagi terjadi pembelahan. Selanjutnya pada 
waktu inkubasi 22 jam sampai 24 jam terjadi penurunan secara drastis dengan log sel 0,537 dan 0,324 , dimana pada fase ini bakteri akan kehabisan nutrisi, jumlah sel akan menurun serta jumlah sel yang mati lebih banyak daripada sel yang hidup. Menurut Setyati, $d k k$, (2015) mengemukakan bahwa fase kematian terjadi penurunan laju pertumbuhan yang disebabkan oleh kekurangan materi pertumbuhan seperti vitamin dan unsur mineral. Kematian juga dapat disebabkan oleh berkurangnya beberapa nutrien esensial dalam media atau karena terjadinya akumulasi autotoksin dalam media atau kombinasi dari keduanya.

\section{SIMPULAN}

Berdasarkan hasil penelitian yang telah dilakukan, maka dapat disimpulkan bahwa bakteri kitinolitik yang diisolasi dari cangkang rajungan (Portunus pelagicus) memiliki kemampuan dalam mendegradasi kitin, hal ini dibuktikan dengan adanya zona bening dengan indeks kitinolitik sebesar 1. Karakteristik bakteri kitinolitik yang berasal dari cangkang rajungan (Portunus pelagicus) menunjukkan isolat bakteri kitinolitik merupakan bakteri Gram negatif berbentuk batang. Awal fase logaritmik terjadi pada waktu inkubasi 2 jam hingga 10 jam.

\section{DAFTAR PUSTAKA}

Arnold, L.S., Solomon, N.A. 1986. Manual of Industrial Microbiology and Biotechnology.
American Society for Microbiology Washington $D C: 15-36$.

Cahyani, L. 2013. Pemanfaatan Tepung Cangkang Udang Sebagai Media Produksi Kitinase Oleh Bakteri Kitinolitik Isolat 26. Skripsi. Jurusan Biologi. Fakultas Matematika dan IImu Pengetahuan Alam. Universitas Jember. Hal. 1-6.

Chasanah, E., IImi, M., Mangunwardoyo, W. 2009. Penapisan Bakteri Kitinolitik dari Limbah Pengolahan Udang. Jurnal Pascapanen dan Bioteknologi Kelautan dan Perikanan. 4(1) : 59-61.

Chasanah, E., Fawzya, Y.N., Poernomo, A. 2014. Enzim Kitinolitik (Fungsi dan Peran). Penerbit ITB. Bandung. Hal. 11-35.

Dewi, I.M. 2008. Isolasi Bakteri dan Uji Aktivitas Kitinase Termoflik Kasar Dari Sumber Air Panas Tingi Raja, Simalungun Sumatera Utara. Tesis. Sekolah Pascasarjana. Universitas Sumatera Utara Medan. Hal. 631.

Fitriani, V., Maizeli, A., Megahati, R.R.P. 2018. Isolation and Identification Of Penicillin Acylase Producing Bacteria Originated From Cow Intestine. International Journal of Scientific and Research Publication. 8(3) : 187-190.

Harman, G.E., Hayes, C.K., Lorito, M., Broadway, R.M., Dipietro, A., Peterbauer, C., Tronsmo, A. 1993. Chitinolytic Enzymes of Trichoderma harzianum: Purification of Chitobiosidase and Endochitinase. Phytopathology. Journal Molecular Pathology. 83(3): 1-6.

Kamil, Z., Rizk, M., Saleh, M., Moutafa, S.. 2007. Isolation and Identification Soil Chitinolytic Bacteria and their Potential in Antifungal Biocontrol. Global Journal Molekular Sciences. 2(2) : 57-66.

Purkan, Azizah, B., Baktir, A., Sumarsih, S. 2014. Eksplorasi Bakteri Kitinolitik dari Sampah Organik: Isolasi dan Karakterisasi 
Enzim Kitinase. Jurnal Molekul. 9(2): 129133.

Purkan, P., Baktir, A., Sayyidah, A.R. 2016. Produksi Enzim Kitinase Dari Aspergillus niger Menggunakan Limbah Cangkang Rajungan Sebagai Induser. Jurnal Kimia Riset. 1(1) : 34-38.

Respati, N.Y. 2017. Optimasi Suhu dan pH Media Pertumbuhan Bakteri Pelarut Fosfat dari Isolat Bakteri Termofilik. Jurnal Biologi. 6(7): 423-429.

Setyati, W.A., Martani, E., Triyanto, Subagiyo, Zainuddin, M. 2015. Kinetika Pertumbuhan dan Aktivitas Protease Isolat 36k dari Sedimen Ekosistem Mangrove, Karimunjawa, Jepara. Jurnal IImu Kelautan. 20(3): 163-169

Sulistijowati, R. 2012. Potensi Lactobacillus acidophilus sebagai biopreservatif pada rebusan daging ikan tongkol. Jurnal IJAS. 2(2): 604.

Suryani, W. 2016. Isolasi dan Identifikasi Mikroorganisme Kitinolitik Asal Limbah Cairan Rumen Sapi Serta Optimasi Produksi Enzim Kitinase. Skripsi. Universitas Haluoleo Kendari. Kendari. Hal. $1-26$.

Soeka, Y.S., Triana E. 2016. Pemanfaatan Limbah Kulit Udang untuk Menghasilkan Enzim Kitinase dari Streptomyces macrosporeus InaCC A454. Jurnal of Applied Chemistry. 18(1) : 91-101.

Younes, I., Bellaaj, O.G., Nasri, R., Chaabouni, M., Rinaudo, M., Nasri M. 2012. Chitin and Chitosan Preparation From Shrimp Shells Using Optimized Enzymatic Deproteinization. Journal Process Chemistry. 47: 2032-2039. 